\title{
Immigration, settlement, and density-dependent mortality of a larval and early postlarval 0-group plaice (Pleuronectes platessa) population in the western Wadden Sea
}

\author{
H. W. van der Veer \\ Netherlands Institute for Sea Research, P.O. Box 59, 1790 AB Den Burg Texel, The Netherlands
}

\begin{abstract}
Mortality factors operating in a temporarily isolated 0-group plaice population in the western Wadden Sea have been examined from information on larval immigration, subsequent settlement and changes in demersal densities. Larvae entered the western Wadden Sea every year from the end of February to the beginning of May. In years of strong larval abundance the main period of arrival seemed somewhat delayed from March to April. As a result, between-years mean length and density of the settled population showed an inverse relation on June 1. Density-dependent mortality was observed among plaice up to about $35 \mathrm{~mm}$, with instantaneous mortality rates ranging up to $0.06 \mathrm{~d}^{-1}$ during and shortly after settling of the larvae. Arguments are given that, although in the coastal zone pelagic predators are present (several coelenterate species), the main density-dependent mortality processes operate in the demersal phase. The larval data further showed that level of yearclass strength was established early in life, during the planktonic stage in the open sea. Observed density-dependent mortality in the Wadden Sea reduced the between-year variation in year-class strength generated in the open sea egg and larval stages from a coefficient of variation of $62 \%$ during larval immigration to $30 \%$ after settling in June.
\end{abstract}

\section{INTRODUCTION}

From the onset of intensive fisheries research in the beginning of this century, interest has focussed on factors determining variation in year-class strength. Hjort (1914) put forward the hypothesis that year-class size is controlled during a critical phase in the early life history of the fish, when numbers of individuals are at a maximum. The mechanisms involved can be distinguished into density-independent processes related to fluctuations in the physical environment, and density-dependent processes caused either by predation or food competition. Since the various mechanisms may operate simultaneously, a thorough analysis of the factors controlling the ultimate size of a year-class is generally very difficult.

Most marine fish species show large year-to-year fluctuations in recruitment of juveniles to the parent stock (Daan 1978, Holden 1978, Jones \& Hislop 1978 , Sahrhage \& Wagner 1978), which implies that in these species density-dependent mortality factors are of rela- tively minor importance. The North Sea plaice population (Pleuronectes platessa L.) is one of the few exceptions, showing relatively small variations in recruitment (Bannister et al. 1974, Bannister 1978, Rauck \& Zijlstra 1978). In this species, recruitment seems to be stabilized by density-dependent mortality factors and therefore offers excellent opportunities for studying such factors.

Extensive studies on the pelagic phase of North Sea plaice by Bannister et al. (1974) and Harding et al. (1978) reveal high mortality rates in egg and larval stages, but fail to demonstrate any density-dependent mortality.

Population control during the subsequent post-larval demersal phase has been the subject of a number of studies in British bays (Riley \& Corlett 1966, Macer 1967, Steele \& Edwards 1970, Lockwood 1972, 1980) and in the continental Wadden Sea (Rauck \& Zijlstra 1978, Zijlstra et al. 1982). These studies suggest a positive relation between mortality and density in post-larval plaice, by which the between-year fluctua- 
tions in abundance generated during the early pelagic phase can be moderated. In British bays this densitydependent mortality operates during the whole of the summer period (Lockwood 1980), while in the Wadden Sea density-dependent mortality seems to be restricted to the period during and just after settlement of plaice larvae (Rauck \& Zijlstra 1978, Zijlstra et al. 1982).

The impact of some planktonic predators on larval plaice during immigration of larvae into the Wadden Sea was the subject of a previous paper (van der Veer 1985). The present paper focusses attention on mortality processes occurring during and shortly after larval settlement. Information on larval immigration, settlement, and changes in demersal densities was collected with the object of estimating mortality rates for different size groups separately.

\section{MATERIAL AND METHODS}

Description of the area. The area selected for this study is part of a large tidal flat system in the western Wadden Sea (Fig. 1). The intertidal area of the Balgzand (about $52 \mathrm{~km}^{2}$ ) is isolated from other tidal flats by dikes in the south and west and for the remainder by tidal channels ranging in depth from 5 to $20 \mathrm{~m}$. A tidal

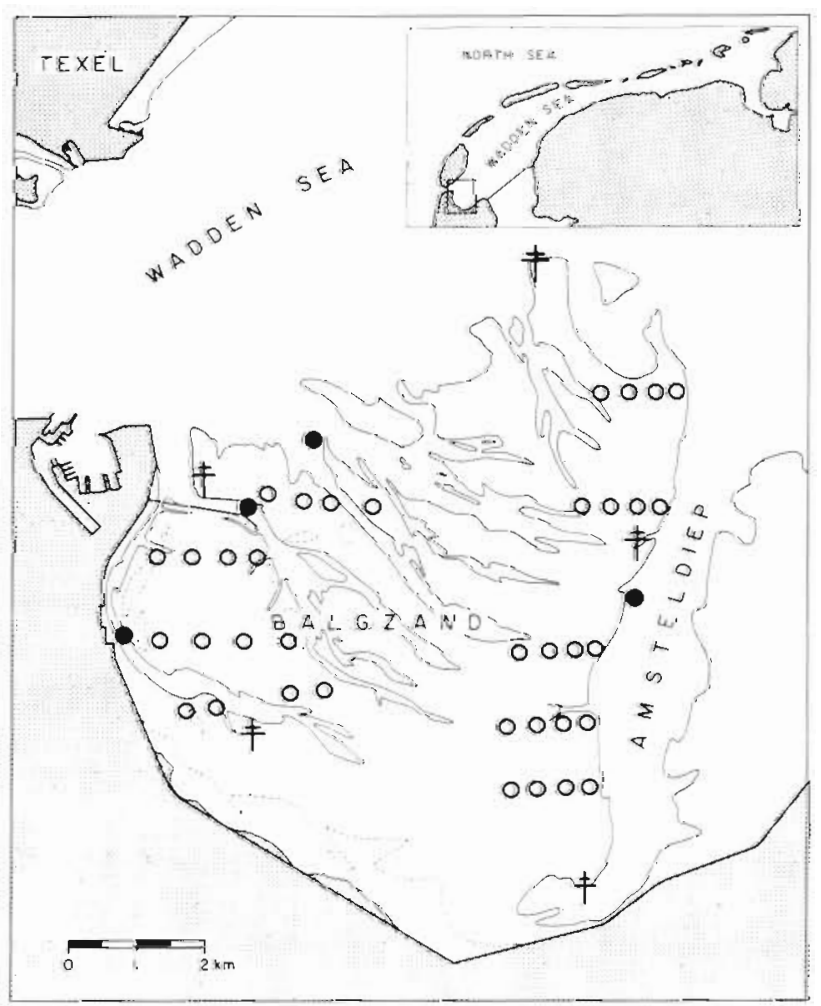

Fig. 1. Location of the Balgzand. Pelagic ( $\bullet$ ) and demersal (O) sampling stations are indicated together with the position of the tide gauges $(\ddagger)$ watershed, i.e. an area where opposite tidal streams meet, runs about $2 \mathrm{~km}$ along the flats parallel to the Amsteldiep tidal channel (de Boer 1978). The area consists of barren flats with only a few mussel beds in the northwest part. Median grain size and silt content respectively are about $150 \mu \mathrm{m}$ and $5 \%$ and there is a gradient from coarse sand in the northerly, more exposed flats to fine sands and mud in the sheltered southern areas (Dapper \& van der Veer 1981). Normally the flats are drained for 2 to $4 \mathrm{~h}$ and submerged for 8 to $10 \mathrm{~h}$ of the tidal cycle. At high water most of the area is covered by 1.0 to $1.5 \mathrm{~m}$ of mostly very turbid water, the actual depth depending on weather conditions and lunar phase. The flats are intersected by numerous small gullies. During the later phase of the ebb the water recedes through these gullies to the main tidal channel. The food of the plaice, consisting of meio- and macrobenthos, is present in densities of respectively about 1.5 and $30 \mathrm{~g}$ ash free dry weight $\mathrm{m}^{-2}$ (Beukema 1974, Witte \& Zijlstra 1984).

Plankton sampling. Plankton sampling, aimed at estimating the numbers of larvae that entered the area through the tidal channels just before settling, was carried out at weekly intervals from February until May-June in 1980, 1981, and 1982. Usually 2 to 4 tidal periods were sampled every week, during both the day and night, at fixed stations in 1 of the 4 main tidal channels (Fig. 1) that supply the Balgzand with water (de Boer 1978). During each ebb and flood tide at least 5 samples were collected.

Double oblique hauls were made using nets with a mouth area of $0.7 \mathrm{~m}^{2}$ and a length of $5 \mathrm{~m}$. The nets were constructed of polyamid plankton gauze (Monodur 2000) with a mesh size of $2 \times 2 \mathrm{~mm}$. The duration of the hauls varied between 10 and 45 min depending on the strength of the current and the abundance of the alga Phaeocystis pouchetti and the ctenophore Pleurobrachia pileus. The total mesh area of the net $\left(12 \mathrm{~m}^{2}\right)$ was sufficiently large to prevent serious overflow, even during blooms of these species (van der Veer \& Sadée 1984). The amount of water filtered, measured by a flow meter mounted in the mouth of the net, varied between 300 and $2000 \mathrm{~m}^{3}$ per haul. Further details of the method are given in van der Veer (1985).

All sampled material was preserved in a $4 \%$ neutral formaidehyde-seawater solution. The fish larvae were sorted into morphological stages as described by Ryland (1966) and measured to the nearest $\mathrm{mm}$ total length within 3 mo. No correction was made for shrinkage, since both Lockwood (1973) and Dapper (1978) found that, for plaice, shrinkage in $4 \%$ formaldehyde was negligible.

No correction was made for net efficiency, since a comparison of day and night catches did not suggest an increasing net avoidance with length (van der Veer 
1985). For each haul numbers were converted into densities per $1000 \mathrm{~m}^{3}$ (ind $1000 \mathrm{~m}^{-3}$ ), and the arithmetic mean was used as index of abundance.

Consistently during both the ebb and flood tide, the variance surpassed the arithmetic mean, pointing to an uneven distribution of the larvae in the water mass. Confidence limits for such distributions can be computed by using the factors derived from a logarithmic $(x+1)$ transformation and applying them to the arithmetic mean of the samples (Elliott 1977). For the $95 \%$ confidence limits these factors of the Student's $t$-distribution range between 2.09 and 2.02, depending on the numbers of hauls made (20 to 40 ). Therefore, the $95 \%$ confidence limits would lie between 47 and $209 \%$ of the mean.

Demersal sampling. Demersal fishing was carried out at 2 wk intervals during the period of larval settlement from February until June-July in 1980, 1981, and 1982 on a grid of 36 stations distributed over the area (Fig. 1).
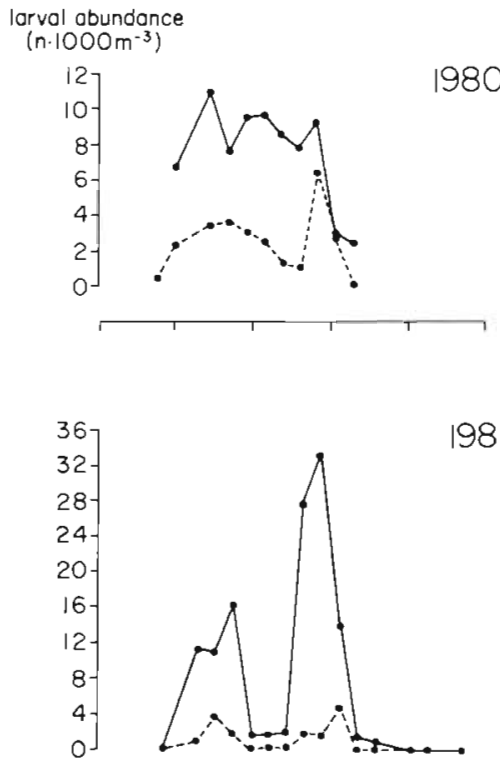

1981

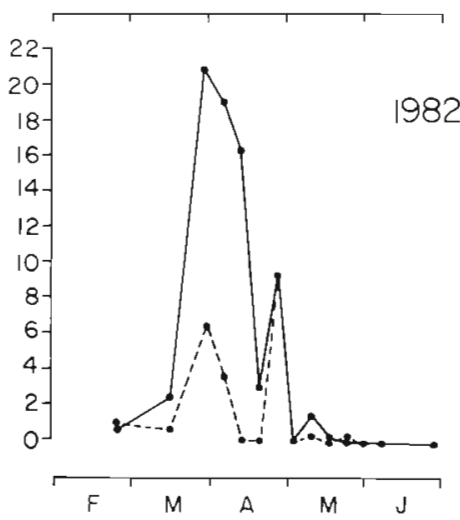

Fig. 2. Pleuronectes platessa. Mean abundance of pelagic plaice larvae (ind $1000 \mathrm{~m}^{-3}$ ) in the gullies near the Balgzand area during flood ( - ) and ebb (-- ) tide
Hauls were made with a $1.90 \mathrm{~m}$ beam trawl with 1 tickler chain and a mesh size of $5 \times 5 \mathrm{~mm}$, towed by a rubber dinghy with an outboard motor ( $25 \mathrm{HP}$ ) at a speed of approximately $35 \mathrm{~m} \mathrm{~min}^{-1}$, following Riley \& Corlett (1966). All sampling was carried out during daytime and was restricted to a period of $3 \mathrm{~h}$ around high water: during this tidal phase the distribution of juvenile plaice appeared to be more or less random on the tidal flats (Kuipers 1977). The exact length of a haul was assessed with a meter-wheel fitted outside the trawl. Each haul represented a surface area of at least $200 \mathrm{~m}^{2}$.

Catches were preserved in a $4 \%$ formaldehyde solution. 0-group plaice were sorted into morphological stages as described by Ryland (1966) and measured in mm size classes. The numbers caught were corrected for mesh selection, since considerable losses in the lower size ranges may occur (Dapper 1978). Losses other than those due to mesh selection were expected to be negligible (Kuipers 1975). The corrected numbers were converted into densities per $1000 \mathrm{~m}^{2}$ (ind $1000 \mathrm{~m}^{-2}$ ) and the arithmetic mean of all stations sampled during a survey was calculated as an index of abundance for the randomly distributed population on the whole area at high water.

During the period June to September, when the population had stabilized, the $95 \%$ confidence limits of the arithmetic mean were on the order of $35 \%$ of the mean (Zijlstra et al. 1982). At least the same order of magnitude was expected for the period prior to June.

\section{RESULTS}

\section{Plankton data}

Fig. 2 shows the mean abundance of larval plaice in the plankton during ebb and flood. Larvae were caught in low numbers at the end of February and remained present in the plankton until the beginning of May. In 1980 larval densities at flood tide stayed on a more or less constant level between February and May, while in 19812 peaks occurred. In 1982 there was 1 period of high abundance.

In the flood catches larvae were all in morphological Stages 4 and 5, but the proportions differed between the 3 yr (Fig. 3A). In all years there was a gradual shift towards the higher developmental stages during the period of immigration, which corresponded to some extent to an increase in the mean length towards the end (Fig. 3B).

Flood tide catches were consistently higher than ebb catches (Fig. 2), indicating a retention of the larvae in the tidal area during ebb tide. In 1980 there was a negative relation between flood density and retention. 

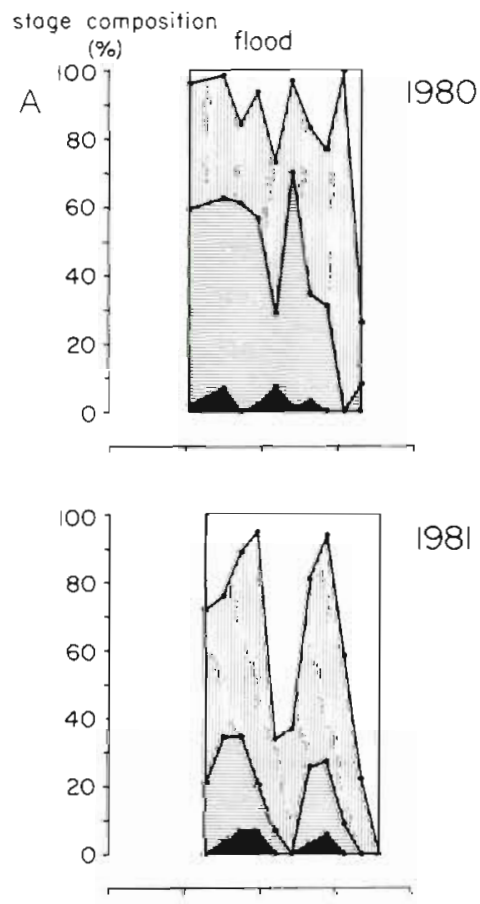

1981

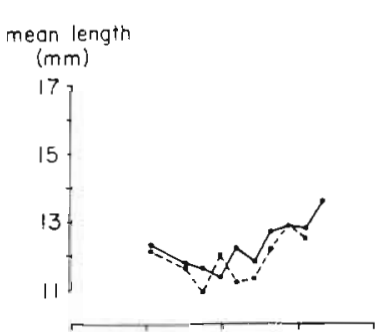

1981
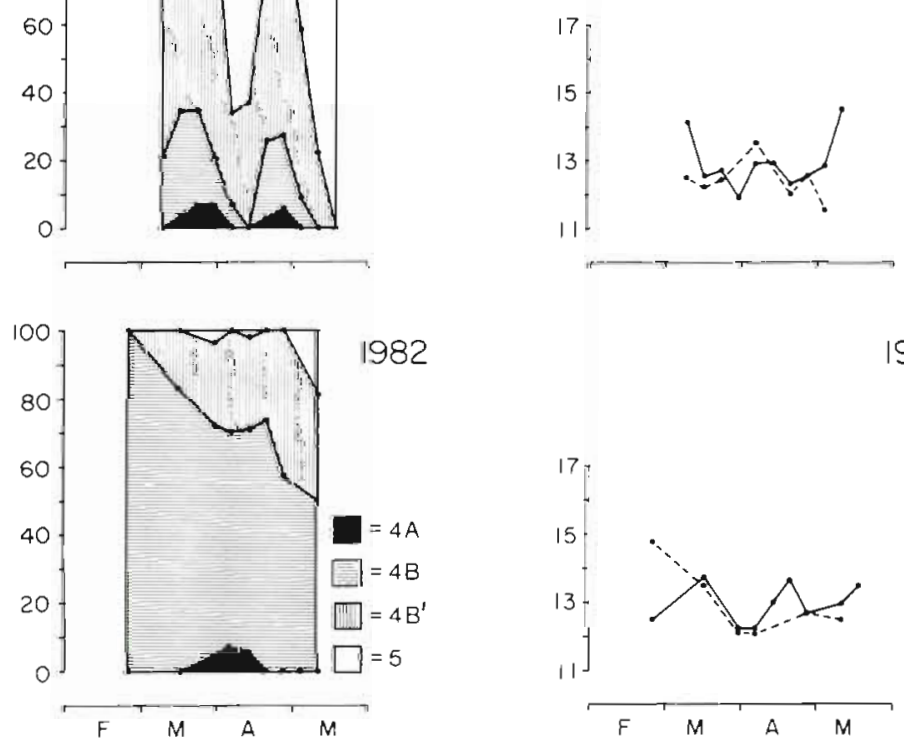

982

1982

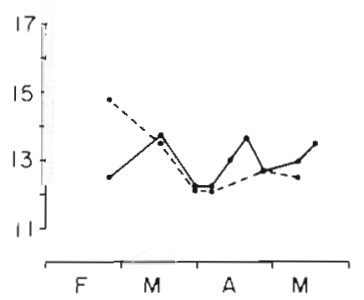

1980

Fig. 3. Pleuronectes platessa. (A) Stage composition of pelagic plaice larvae (\%) during flood tide. (B) Mean length of pelagic plaice larvae $(\mathrm{mm})$ during flood $(-)$ and ebb (...) tide
However, retention varied only between 70 and $100 \%$. As a rule the rate of retention seemed to be independent of the flood abundance (Table 1). From the stage compositions (Table 2) and the retention of each stage (Table 3 ) it could be concluded that about equal fractions of all stages were washed back during ebb tide. This agreed with the fact that mean length of the plaice

Table 1. Pleuronectes platessa. Spearman's rank correlation between mean weekly flood abundance and retention of plaice larvae

\begin{tabular}{|cccc|}
\hline Year & $\begin{array}{c}\text { No. of } \\
\text { observations }\end{array}$ & $\begin{array}{c}\text { Spearman's rank } \\
\text { correlation }\end{array}$ & $\begin{array}{c}\text { Signi- } \\
\text { ficance }\end{array}$ \\
\hline 1980 & 10 & 0.04 & $\mathrm{~ns}$ \\
1981 & 11 & -0.60 & $\mathrm{p}<0.05$ \\
1982 & 6 & 0.16 & $\mathrm{~ns}$ \\
Total & 27 & -0.30 & $\mathrm{~ns}$ \\
\hline
\end{tabular}

Table 2. Pleuronectes platessa. Mean morphological stage composition of plaice larvae during flood and ebb tide (\%)

\begin{tabular}{|lrrrrrr|}
\hline \multirow{2}{*}{ Stage } & \multicolumn{3}{c}{ Flood tide } & \multicolumn{3}{c|}{ Ebb tide } \\
& 1980 & 1981 & 1982 & 1980 & 1981 & 1982 \\
& & & & & & \\
& 2.2 & 2.7 & 2.1 & 3.6 & 3.0 & 9.4 \\
$4 \mathrm{~A}$ & 38.9 & 15.3 & 69.9 & 47.5 & 12.8 & 57.1 \\
$4 \mathrm{~B}$ & 41.6 & 47.6 & 24.9 & 40.1 & 65.3 & 33.7 \\
$4 \mathrm{~B}^{\prime}$ & 17.2 & 34.3 & 3.0 & 8.9 & 19.0 & 0.0 \\
5 & & & & & & \\
\end{tabular}

larvae did not show systematic differences between flood and ebb (Fig. 3B). Mean retention over the whole period of larval immigration was higher in 1981 (88\%) than in 1980 and 1982 (66\%) (Table 3). No clear difference was observed in retention during day or night time. At the end of larval immigration mean length of the larvae increased somewhat due to the shift in stage composition. 
Table 3. Pleuronectes platessa. Mean retention of plaice larvae with ebb tide expressed as percentage of flood densities $(\%)$

\begin{tabular}{|lrrr|}
\hline Stage & 1980 & 1981 & 1982 \\
\hline $4 \mathrm{~A}$ & 50 & 89 & 57 \\
$4 \mathrm{~B}$ & 65 & 90 & 68 \\
$4 \mathrm{~B}^{\prime}$ & 67 & 84 & 51 \\
5 & 68 & 94 & 100 \\
Total & 66 & 88 & 65 \\
\hline
\end{tabular}

\section{Demersal surveys}

Fig. 4A shows the mean abundance of demersal 0 group plaice on the tidal flats. After the appearance of the first specimens in February-March the population increased rapidly to a maximum density of about 150 ind $1000 \mathrm{~m}^{-2}$ in 1980, 350 in 1981, and 300 in 1982. From May onwards numbers declined to a density of about 100 ind $1000 \mathrm{~m}^{-2}$ by the end of July.

In all years the size frequencies of the plaice popula- tion were distributed fairly normally. This has been shown also for previous years by de Vlas (1979). Therefore, for all surveys mean length has been estimated. In all years this mean length of the population remained approximately constant until the end of April, which can be explained by the continuous arrival of new settling larvae. From May onwards mean length increased rapidly up to 5 to $6 \mathrm{~cm}$ in July (Fig. 4B).

The observed increase in mean length has been compared with simulated values using a simple descriptive growth model obtained under excess feeding conditions (cropped fresh musselmeat) for especially small 0 -group plaice up to $5 \mathrm{~cm}$, kept in aerated pails and crates with a layer of sand on the bottom (Glazenburg 1983):

$$
\Delta \mathrm{L}=1.3 \times \mathrm{T}+1.7\left(\mathrm{~mm} \mathrm{mo}^{-1}\right)
$$

where $\Delta \mathrm{L}=$ length increase in $\mathrm{mm} \mathrm{mo}^{-1} ; \mathrm{T}=$ mean temperature in ${ }^{\circ} \mathrm{C}$. Results of later, more detailed experiments supported the validity of the model (Fonds, pers. comm.). Mean daily temperatures could not be measured. Instead high water temperatures on the tidal flats during daytime were used (Fig. 5). These
$A$
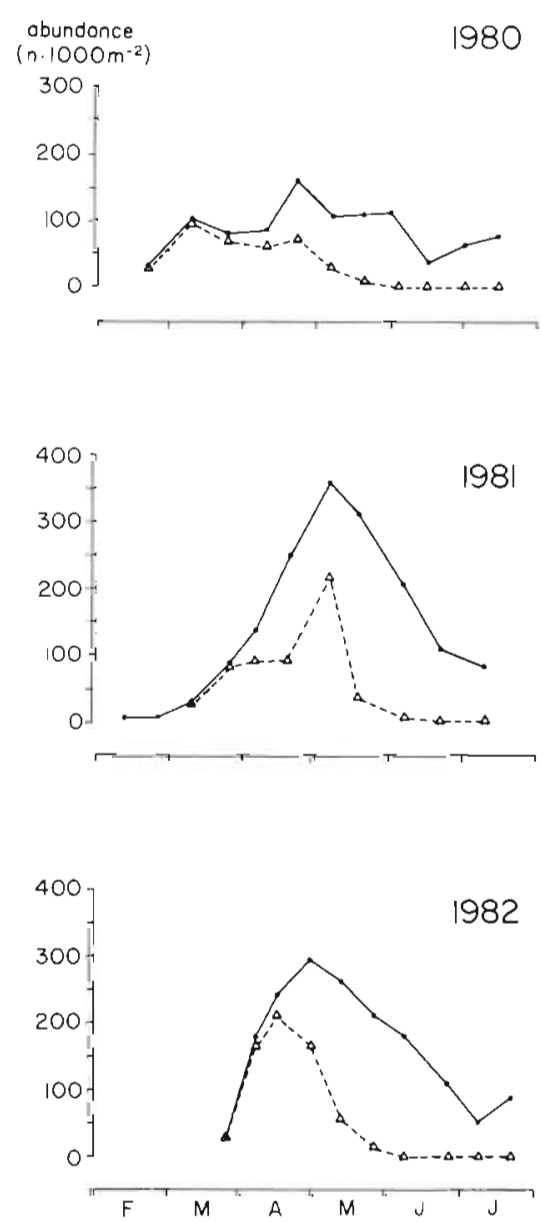

$B$
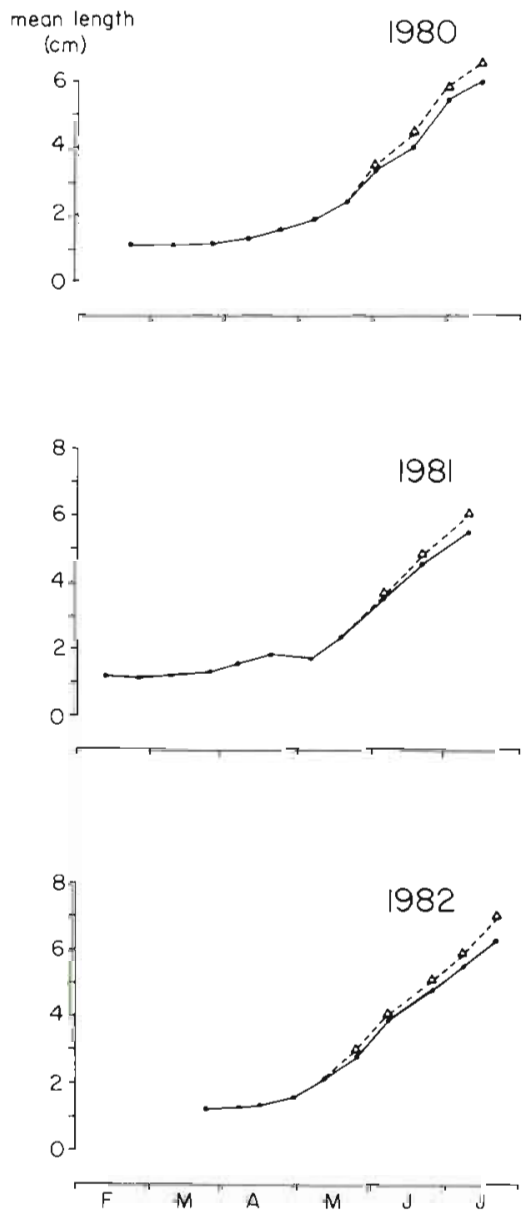

Fig. 4. Pleuronectes platessa. (A) Mean abundance of all 0 -group plaice $(-)$ and of only newly settled plaice [ $\leqslant 15 \mathrm{~mm}$ ] $(--)$ (ind $1000 \mathrm{~m}^{-2}$ ) in 1980,1981 , and 1982. (B) Mean length (mm) of 0-group plaice on the Balgzand in 1980,1981 . and 1982. (-) observed length, (-- -) estimated after growth model of Glazenburg (1983) 


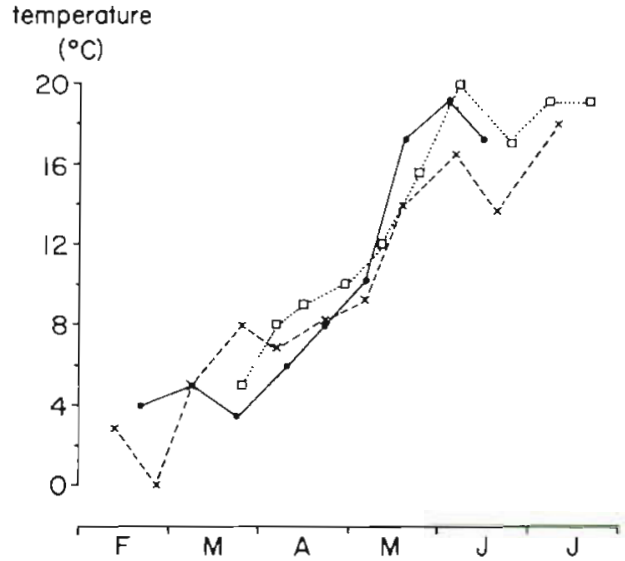

Fig. 5. Water temperature on the tidal flats of the Balgzand at high water during daytime in $1980(\bullet), 1981$ (x), and $1982(\square)$

values are a slight overestimation of the mean daily temperatures and will therefore result in a somewhat too high simulated growth. From the beginning of May onwards there was a high similarity between the observed and simulated values (Fig. 4B), which would imply that feeding conditions were not limiting growth. The discrepancy that developed between the 2 curves in the course of the period from May to July is caused by the temperature effect and probably by the decreasing validity of the experimental growth model for plaice larger than $5 \mathrm{~cm}$.

\section{Mortality}

On the assumption that the exchange between the Balgzand area and the deeper surrounding channels was negligible, the abundance of 0-group plaice would be controlled by settlement and mortality during spring and early summer.

The observed retention of planktonic plaice larvae per $1000 \mathrm{~m}^{3}$ (Fig. 2) has been converted into an assessment of the settlement of larvae per $1000 \mathrm{~m}^{2}$ on the basis of the estimated volume of water covering the area at high water. Since this volume varied as a consequence of lunar phase and wind conditions, a number of self-registering tide gauges were placed around the tidal flats from February to May in all years (Fig. 1). The resultant information on water level in combination with a recent sounding chart (courtesy of Rijkswaterstaat) yielded estimates of the daily volume of water covering the Balgzand at high tide with a accuracy of about $95 \%$. This volume varied between 5 and $50 \times 10^{6} \mathrm{~m}^{3}$, depending on lunar phase and wind stress (van der Veer 1983).

Fig. 6. shows weekly estimates of mean settlement in numbers per $1000 \mathrm{~m}^{2}$ per tide in the course of the
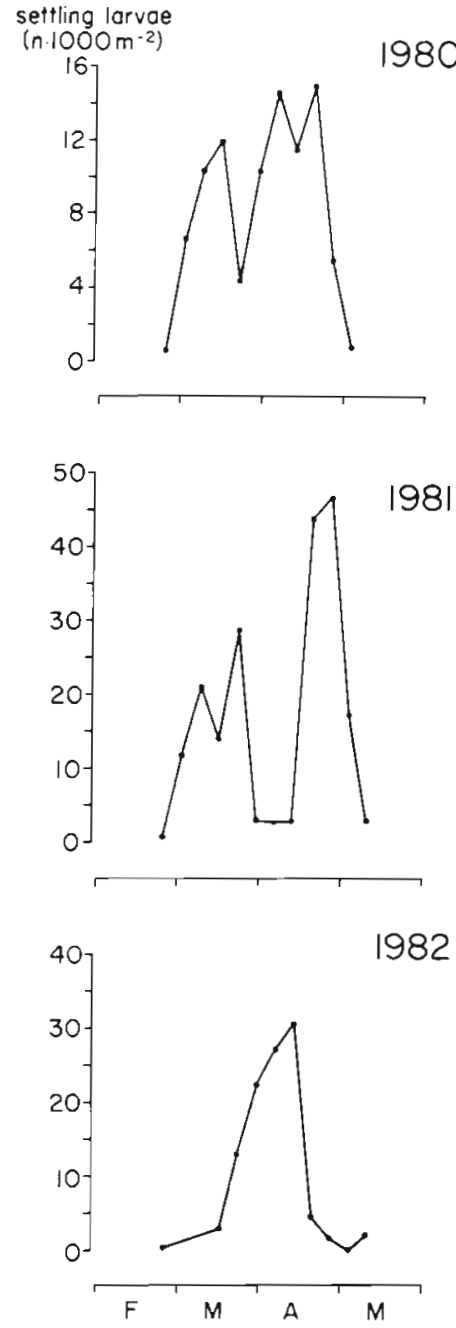

Fig. 6. Pleuronectes platessa. Weekly mean settlement of larval plaice (ind $1000 \mathrm{~m}^{-2}$ ) per tide on the Balgzand, estimated after the retention of larvae and the daily amount of water covering the tidal flats at high water

season. These larvae varied in size between 10 and $15 \mathrm{~mm}$, as is indicated by the total length compositions (Fig. 7).

With these numbers of settlers during a period from 0 to $t\left(S_{(0-t)}\right)$, estimated according to: mean settlement per tide $\times$ number of tides during the period 0 to t, the size of the demersal population at the start $\left(\mathrm{N}_{0}\right)$ and the size at the end $\left(\mathrm{N}_{t}\right)$ of the period considered, the mean daily mortality $\mathrm{Z}\left(\mathrm{d}^{-1}\right)$ among the whole 0 -group population could be calculated according to:

$$
Z_{(0-t)}=\frac{1}{t} \ln \frac{\left(N_{0}+S_{(0-t)}\right)}{N_{t}}\left(d^{-1}\right)
$$

where $\mathrm{t}=$ number of days between 0 and $\mathrm{t}$.

The Z-values obtained over the period February to May varied between approximately 0 and $0.11 \mathrm{~d}^{-1}$, 

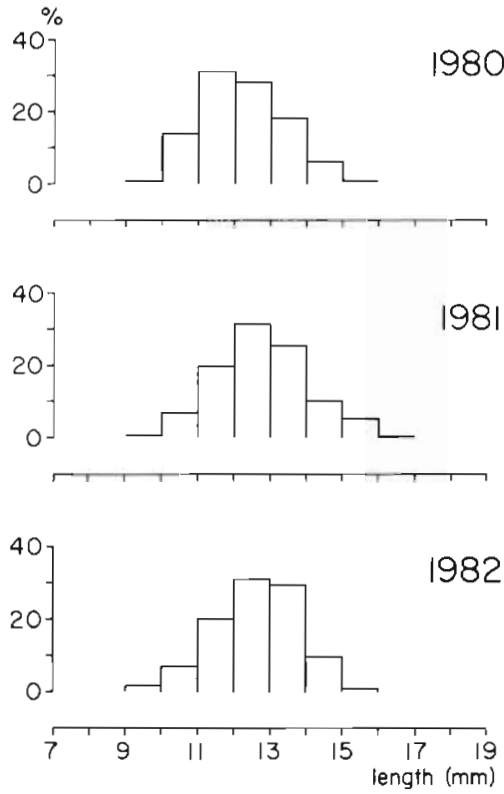

Fig. 7. Pleuronectes platessa. Mean length composition (mm) of settling larvae in 1980, 1981, and 1982

with a mean of about $0.04 \mathrm{~d}^{-1}$. Part of the variation in $\mathrm{Z}$ could be explained by differences in density as suggested by the significant relation in Fig. 8 between density and mortality (Spearman's rank correlation $\left.\mathrm{r}_{\mathrm{s}}=0.49 ; \mathrm{p}<0.05\right)$.

In order to detect the stage in which this densitydependent mortality might occur, separate size groups were analysed by the method described by Zijlstra et al. (1982). The apparent optimal growth from May on, according to Fig. 4B, justified the use of the growth model for the preceding period, to compute the transfer of plaice through the size classes by growth. For the smallest size group, $\leqslant 15 \mathrm{~mm}$, corresponding to newlysettled plaice, an expected density at time $t\left(N_{t e}\right)$ could be calculated on the basis of estimated settlement $\left(\mathrm{S}_{(0-t)}\right)$ and the numbers disappearing by growth $\left(\mathrm{N}_{\mathrm{g}}\right)$ into the next size class between successive surveys (according to Eq. [1]), from:

$$
\mathrm{N}_{\mathrm{te}}=\mathrm{N}_{0}+\mathrm{S}_{(0-\mathrm{t})}-\mathrm{N}_{\mathrm{g}} \text { (ind } 1000 \mathrm{~m}^{-2} \text { ) }
$$

By comparing this expected density with the observed abundance in the next survey $\left(N_{t}\right)$, mean daily mortality rates $\mathrm{Z}\left(\mathrm{d}^{-1}\right)$ for the size group $\leqslant 15 \mathrm{~mm}$ were calculated by:

$$
\mathrm{Z}_{(0-\mathrm{t})}=\frac{1}{\mathrm{t}} \ln \frac{\mathrm{N}_{\mathrm{te}}}{\mathrm{N}_{\mathrm{t}}}\left(\mathrm{d}^{-1}\right)
$$

Similarly, with the aid of the growth model (Eq. [1]), mortality rates for the larger size groups were computed assuming that with a growth of $y$ mm between 2 successive surveys, all fish $>\chi \mathrm{mm}$ at $\mathrm{t}_{0}$ will correspond with all fish $>(x+y) m$ at $t_{t}$. The difference between expected and observed density should be caused by mortality. Fig. 9 shows the relations between density and mortality for the 4 different size groups considered.

For plaice $\leqslant 15 \mathrm{~mm}$, mortality was significantly correlated with density $\left(r_{s}=0.82 ; p<0.01\right)$. Also signifi-
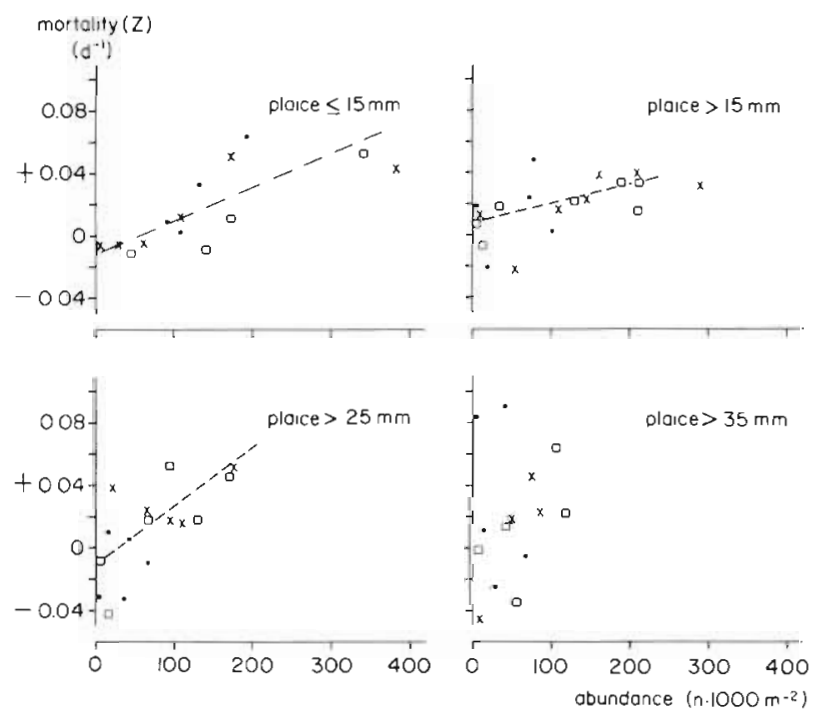

Fig. 9. Pleuronectes platessá. Relation between mean daily mortality $\mathrm{Z}\left(\mathrm{d}^{-1}\right)$ between 2 successive demersal surveys and mean abundance of 0 -group plaice for different size classes during Feb to Jun. Combined data of $1980(\bullet), 1981$ (x), and 1982 (口)

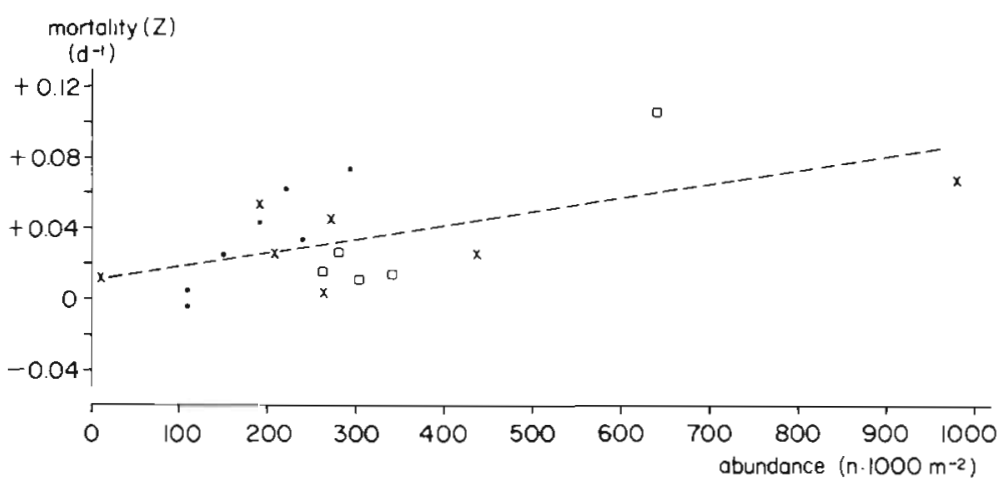

Fig. 8. Pleuronectes platessa. Relation between mean daily mortality $\mathrm{Z}\left(\mathrm{d}^{-1}\right)$ between 2 successive demersal surveys and mean abundance of 0 -group plaice corrected for larval settlement during Feb to Jun. Combined data of $1980(\bullet)$, $1981(x)$, and $1982(\square)$ 
cant correlations of mortality with density were found for all plaice $>15 \mathrm{~mm}$ and $>25 \mathrm{~mm}\left(\mathrm{r}_{\mathrm{s}}=0.60, \mathrm{p}<0.01\right.$ $\mathrm{r}_{\mathrm{s}}=0.70, \mathrm{p}<0.01$ respectively). For all plaice $>35 \mathrm{~mm}$, however, the correlation was no longer significant ( $r_{s}=0.30$, n.s.).

Since abundance and mortality are not independent variables, it cannot be excluded that part of the correlation originates from statistical effects. However, the differences between the correlations for the various size groups in Fig. 9 suggest that at least partly real density-dependent processes are operating.

\section{DISCUSSION}

\section{Immigration and settlement of larvae}

Plaice larvae immigrating into the western Wadden Sea originate from spawning grounds in the Southern Bight and the Eastern English Channel (Simpson 1959, Houghton \& Harding 1976, Talbot 1976, 1978). After spawning, which peaks in January-February (Harding et al. 1978), the developing eggs and larvae are transported by residual currents towards the coastal nursery areas (Houghton \& Harding 1976, Zijlstra 1972).

The first larvae appear in the western Wadden Sea at the beginning of March (Creutzberg et al. 1978), which is early compared to the arrival in the German Wadden Sea (Rauck 1974, Berghahn 1983) and some British bays (Macer 1967, Edwards \& Steele 1968, Lockwood 1972). There the first demersal specimens are not observed before April or May. During the period of immigration, larval abundance fluctuates considerably both within and between years. Also the period of and the numbers during maximum abundance vary. Such fluctuations may be caused either by different rates of development and survival at sea, or by interruptions in transport by the residual currents. After arrival in the Wadden Sea the larvae accumulate in the area by settling from the plankton onto the tidal flats, a process which is probably stimulated by the favourable food conditions on the flats (Creutzberg et al. 1978).

The process of settlement is indicated by the consistently higher abundance during flood tide compared to ebb tide and also by the continuous increase in numbers of small demersal plaice on the tidal flats from February until May. Creutzberg et al. (1978) mentioned a time delay of about $40 \mathrm{~d}$ between the entrance of larvae into the Wadden Sea and subsequent settling on the Balgzand. However, the data of the present study suggest that retention of larvae and settling on the tidal flat are features of the same phenomena (Fig. 10).

Retention varies substantially in the course of the immigration period and between years. In the tidal

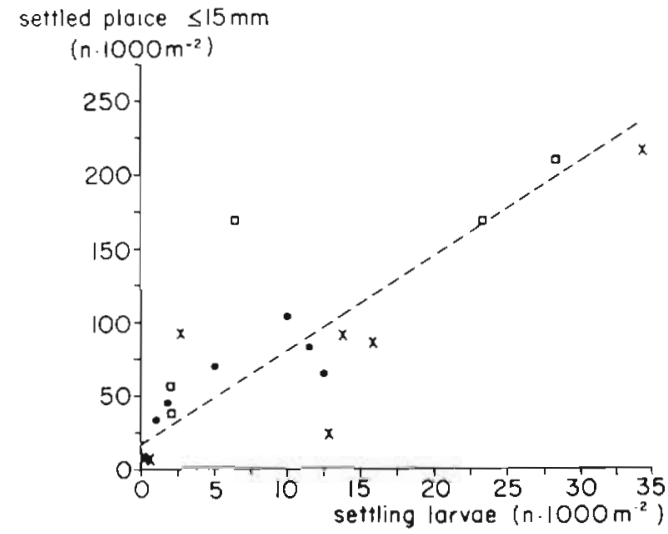

Fig. 10. Pleuronectes platessa. Weekly number of settling plaice larvae (ind $1000 \mathrm{~m}^{-2}$ ) per tide estimated from plankton data aqainst simultaneous observed abundances of demersal settled plaice $\leqslant 15 \mathrm{~mm}$. (•) 1980; (x) 1981, (ㅁ) 1982

inlets retention rate increased with the development of the larvae (Creutzberg et al. 1978, Rijnsdorp \& van Straten 1982). This relation is less clear for the smaller tidal gullies of this study. In 1981 however, when larval development was on the average most advanced, the highest retention rate was obtained (Tables $2 \& 3$ ).

\section{Demersal abundance and growth}

The seasonal abundance of demersal plaice on the Balgzand showed a consistent pattern: increasing numbers up to the first part of May followed by a sharp reduction.

Peak densities varied considerably from year to year, from 200 up to 350 ind $1000 \mathrm{~m}^{-2}$ in the present study and even up to 500 ind $1000 \mathrm{~m}^{-2}$ in 1978 (Zijlstra et al. 1982). During the summer period from June 1 onwards, there are no indications that growth is food limited (Kuipers 1977, Zijlstra et al. 1982). Also in this study simulated growth, calculated according to an empirical growth model determined under excess feeding conditions, corresponds well with the observed values in all $3 \mathrm{yr}$, despite variations in abundance. Our data for 1980 to 1982 fit well in the inverse relation found by Zijlstra et al. (1982) between the index of year-class strength, calculated as the mean of the 2 highest abundances of plaice between 20 and $35 \mathrm{~mm}$, and the mean length on June 1 , which seems to suggest density-dependent growth in early life (Fig. 11). The strong relation between mean larval flood tide abundance over the whole period of immigration and the index of year-class strength over this period $\left(r_{s}=0.83\right.$, $p<0.05$, Fig. 12A) means that a high larval abundance results in a low mean length at June 1. Nevertheless, over the whole larval period both mean length and retention fraction in the larval stage just prior to sett- 


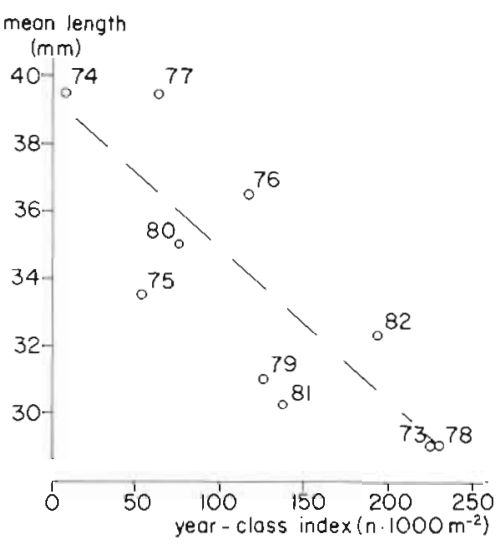

Fig. 11. Pleuronectes platessa. Relation between index of year-class strength of the Balgzand (ind $1000 \mathrm{~m}^{-2}$ ) and mean length (mm) on June 1 after Zijlstra et al. 1982 and this study

ling appear to be independent of density (Fig. 12B, C). Therefore, the suggestion given by Zijlstra \& Witte (1982), that a difference in timing of larval immigration is responsible for the apparent density-dependent growth, appears to be the most likely explanation. A shift in main immigration from March to April during years of high abundance will result in relatively large numbers of newly-settled plaice at the start of the growth season in May and thus lead to a relatively lower mean length on June 1 . This explanation finds support in the fact that in the 2 most abundant years (1981 and 1982) larval densities are relatively higher during April, whereas in the weaker larval year of 1980 the densities are almost comparable during March and April.

\section{Mortality}

For an accurate calculation of mortality rates, precise estimates of pelagic and demersal densities are required. Larval densities are determined by date of sampling, location, tide, depth, and diel period (Rijnsdorp et al. 1985) and all these factors have been incorporated in the framework of the sampling program. Interference may also occur by problems of net efficiency; however, net avoidance by the pelagic larvae does not seem likely (van der Veer 1985). The method used to estimate settlement per unit surface from larval retention and the volume of water on the tidal flats might also have biassed the results. The good correspondence between the size distribution of the pelagic settling $4 \mathrm{~A}, 4 \mathrm{~B}$ and $4 \mathrm{~B}^{\prime}$ larvae with that of the settled demersal larvae support the validity of the method at least qualitatively (Table 4). A quantitative

Table 4. Pleuronectes platessa. Size distribution (\%) of Stage $4 \mathrm{~A}, 4 \mathrm{~B}$ and $4 \mathrm{~B}^{\prime}$ larvae: settling pelagic larvae (calculated from flood-ebb differences) and observed simultaneous demersal settled larvae on the Balgzand. Mean percentages of 1980 to 1982

\begin{tabular}{|ccc|}
\hline $\begin{array}{c}\text { Larval size } \\
(\mathrm{mm})\end{array}$ & $\begin{array}{c}\text { Pelagic settling } \\
\text { larvae (\%) }\end{array}$ & $\begin{array}{c}\text { Demersal settled } \\
\text { larvae (\%) }\end{array}$ \\
\hline 8 & 1 & 2 \\
9 & 9 & 11 \\
10 & 24 & 28 \\
11 & 30 & 30 \\
12 & 24 & 22 \\
13 & 9 & 5 \\
14 & 3 & 2 \\
\hline
\end{tabular}

justification is found in the linear relation $\left(r_{s}=0.74\right.$, $p<0.01$ ) between the estimated number of pelagic larvae retained and settled on the flats and the simultaneous abundance of demersal plaice $\leqslant 15 \mathrm{~mm}$ (Fig. $10)$. With respect to demersal sampling, previous studies clearly demonstrated the validity of the method (Kuipers 1975, Zijlstra et al. 1982).

The observed changes in density of demersal plaice until the end of larval immigration in May reflect the integrated effect of settlement, possible migration, and mortality. With the accurate estimate of settlement, mortality can be assessed if the plaice population on the Balgzand does not migrate to or from the deeper parts of the surrounding tidal channels. Migrations within the area would be compensated for in the overall estimate of mortality. Investigations by both Creutzberg \& Fonds (1971) and Zijlstra et al. (1982) indicate low densities of 0 -group plaice in the deeper channels, at least prior to June-July, which suggests that major migrations do not occur to or from the area during this phase. Similar observations have been made in British waters (Macer 1967, Lockwood 1972).
Fig. 12. Pleuronectes platessa. Relation between index of year-class strength on the Balgzand (ind $1000 \mathrm{~m}^{-2}$ ) and (A) mean larval flood abundance; (B) mean retention percentage; (C) mean flood length (after Creutzberg et al. 1978 and this study)

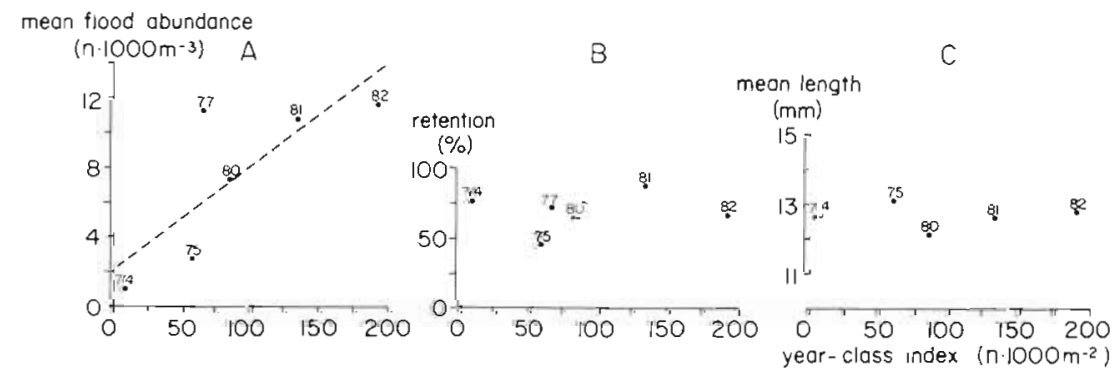


Earlier attempts to estimate mortality rates in postlarval plaice indicate for various areas, such as Red Wharf Bay (Macer 1967), Loch Ewe (Edwards \& Steele 1968), Filey Bay (Lockwood 1972) and the German Wadden Sea (Rauck \& Zijlstra 1978), a decline of mortality with age, as reviewed by Zijlstra et al. (1982). Cushing (1974) suggests that predation will be the main cause of mortality during the early life of fish. and that the inverse relation between mortality and age is the result of a reduced number of potential predators with increasing size. In a previous study on the Balgzand, mortality was estimated at about $0.023 \mathrm{~d}^{-1}$ during April-June and at about $0.005 \mathrm{~d}^{-1}$ during July-August, with the suggestion that mortality in the first period was probably underestimated due to the absence of data on numbers of settling larvae (Zijlstra et al. 1982). The present study largely confirms the earlier observations on mortality rates during the stage of settlement, which are in the order of $0.04 \mathrm{~d}^{-1}$, about 2 times higher than the values given by Zijlstra et al. (1982) and about as high as those found during the egg and larval phases (Harding et al. 1978).

The suggestion of Zijlstra et al. (1982) that mortality may depend on the abundance of the plaice - being higher at higher densities - also finds confirmation in this new and more detailed material. This dependence is significant for all size groups below $35 \mathrm{~mm}$, if data for the 3 yr of sampling are combined. The data of the separate years show more variability, but at least for the size group $\leqslant 15 \mathrm{~mm}$ the data are consistent in this respect for each of the $3 \mathrm{yr}$. A problematic feature is that at low densities zero or even slightly negative mortalities are found. This may be due to a slight overestimation of the growth rate by the model used, which influences the transfer of one size group to another and affects mortalities at various densities to the same extent. Alternatively, migration behaviour may be different at different densities, or the 'noise' in the estimation processes may be higher at low densities. For these smallest demersal plaice up to $35 \mathrm{~mm}$, a trend of decreasing mortality with increasing size is not clearly visible. However, the variation in $Z$ appears to increase in the larger size classes $(-0.01$ to +0.07 for plaice $\leqslant 15 \mathrm{~mm}$ to -0.05 to +0.09 for plaice $>35 \mathrm{~mm}$ ), which may indicate that Z-values were less accurately estimated, partly because of smaller samples. Although the period of density-dependent mortality is rather short, it will have measurable effects on survival. For instance a mortality of $0.01 \mathrm{~d}^{-1}$ reduces the population in $14 \mathrm{~d}$ by $13 \%$, compared with a $57 \%$ reduction at a mortality rate of $0.06 \mathrm{~d}^{-1}$.

For the newly-settled plaice the relation between mortality and density may not be linear, but seems to follow some 'S-shaped' curve as described for predation of small mammals on insects by Holling (1959). A similar suggestion for an S-shaped mortality-density response in 0-group plaice has been found by Lockwood (1980) in British waters. Such a relation indicates either a numerical response - whereby the number of predators increases - or a functional response whereby each individual predator attacks more prey by one or more predators (Solomon 1949). The rapid changes in plaice densities and the immediate effect on mortality suggest a functional response of the predator population through conditioning. However, it is not clear why this should be restricted to newly-settled plaice.

The possibility that density-dependent mortality also acts in the planktonic pre-settling phase in the Wadden Sea cannot be excluded. In the coastal zone important predators are present such as the ctenophore Pleurobrachia pileus and the scyphomedusa Aurelia aurita (van der Veer 1985). Each year they show an enormous numerical increase at the end of larval immigration in early May. Their mass appearance is probably responsible for the sharp drop in the numbers of plaice larvae at that period. However, it seems unlikely that these coelenterates can be the cause of a density-dependent mortality during the whole period of immigration.

Considering possible predators in the demersal phase, Bergman et al. (1976) provided evidence that the brown shrimp Crangon crangon is an important predator on small 0-group plaice on the Balgzand. Predation by shrimps has also been reported for Loch Ewe (Edwards \& Steele 1968) and Red Wharf Bay (Macer 1967), although C. crangon is not the main predator in these latter areas. Other predators on 0 group plaice such as dabs (Macer 1967), cod and lesser weever (Edwards \& Steele 1968) are virtually absent in our area. Cannibalism by larger plaice has been mentioned (Riley \& Corlett 1966, Macer 1967), but no evidence for serious predation of this type has been reported by other authors for British waters (Edwards \& Steele 1968), or the Wadden Sea (Kuipers 1977, de Vlas 1979)

The observed decrease in mortality rates from spring to summer can be explained by a decreasing predation by Crangon crangon, because the larger plaice are less vulnerable to shrimp predation (Bergman et al. 1976). Other predators on larger 0-group plaice in the Wadden Sea include crabs (Bergman et al. 1976), bass (Zijlstra pers. comm.) and birds (Mes pers. comm.), but their numbers are lower than those of the shrimps.

\section{Impact of mortality on year-class strength}

From extensive information available on the egg and larval stages of North Sea plaice (Harding et al. 1978), 
it appears that year-class fluctuations might be generated as early as in the egg stage (Brander \& Houghton 1982). Between-year fluctuations in late egg stage abundance and ultimate recruitment seems to be associated with temperature conditions in the spawning area; low temperatures seem to induce reduced mortalities and a slow rate of development (Harding et al. 1978, Zijlstra \& Witte 1982). However, such correlations between an environmental factor and recruitment may be deceptive and do not necessarily give insight into the underlying causal relations. Gulland (1965) concludes, on the basis of various published correlations, that many of these may be fortuitous and that they should at least be confirmed by an independent new set of data.

The observations on larval and early post-larval abundance near the entrance of the Wadden Sea by Creutzberg et al. (1978) and by this study might offer an opportunity for such an independent check over a period of $6 \mathrm{yr}$. It appears that the annual index of abundance of newly-settled plaice as well as the mean flood abundance of larvae show significant inverse relations with the February temperature near the spawning grounds in the Southern Bight of the North Sea [station: Noordhinder light vessel, position: $\left.51^{\circ} 39^{\prime} \mathrm{N}_{;} 2^{\circ} 34^{\prime} \mathrm{E}\right] \quad\left(\mathrm{r}_{\mathrm{s}}=-0.90 ; \mathrm{p}<0.01\right.$ and $\mathrm{r}_{\mathrm{s}}=$ $-0.71 ; p<0.05$ respectively) (Fig. 13A,B). Low temperatures during the egg and larval stage will undoubtedly slow down the rate of development. In years with a low temperature in February, one may therefore either expect an immigration of larvae in an earlier morphological stage, smaller larvae or a delayed immigration. In 1981 and 1982, when temperatures were relatively low (see Fig. 13) there was no marked effect on the stage of the larvae (Table 2) or on their size (Fig. 12C). The main difference between yearclasses spawned under different temperature conditions appears to be that at higher temperatures larval numbers are more or less constant throughout March and April, whereas at lower temperatures larval abundance is higher in April than in March (Fig. 13C).
Although the main period of immigration appears to be shifted in low temperature years, first settlement does not seem to be delayed in such years. It is not yet clear how temperature affects mortality in the egg and larval stages.

In Table 5 estimates are given of mean abundance at various stages during the early life of the North Sea plaice, together with an index of variability: the coefficient of variation. This coefficient, defined as mean divided by standard deviation, is a measurement for the relative dispersion, independent of the units in which the results are expressed during the various life stages. There is a major increase in the coefficient from the egg stage to Stage I larvae (from 40 to $90 \%$ ), but the value for Stage I larvae is based on only 4 observations and therefore not very reliable. At the entrance to the Wadden Sea the coefficient of variation during the late larval stages is somewhat lower but is still about $62 \%$. After settlement a sharp drop follows to $30 \%$ in July, a value similar to that observed during recruitment at about 2 yr of age. The sharp reduction of the variation between years in the early demersal phase points to some regulation, which supports the suggestion of a density-dependent mortality during and shortly after settling as estimated in Fig. 8 and 9. The fact that the coefficient of variation remains more or less stable up to the age of recruitment indicates the absence of further regulating mechanisms during this period in the nursery.

This picture confirms the hypothesis formulated by Rauck \& Zijlstra (1978) and Zijlstra et al. (1982), that if a regulating mechanism is operating in the nursery at all, it must be confined to the period during or shortly after settlement. Although the order of magnitude of a year-class is determined roughly at the time the pelagic larvae arrive at the entrance of the Wadden Sea, a further readjustment occurs by the densitydependent mortality mechanism, which results in a reduction in year-class strength variations. This conclusion is in accordance with the idea put forward by Gulland (1965), who suggested 2 important periods
Fig. 13. Pleuronectes platessa. Relation between water temperature in Feb on the spawning grounds (from Noordhinder light vessel) with: (A) index of year-class strength of the Balgzand; (B) mean larval flood abundance; (C) mean larval flood abundance seperated for Mar and Apr (according to Creutzberg et al. 1978 and this study)

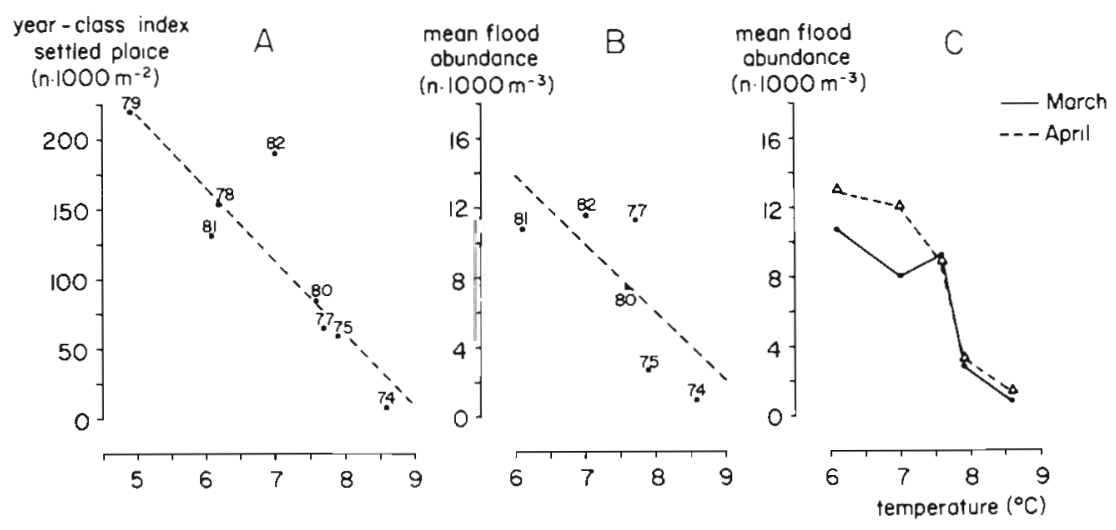


Table 5. Pleuronectes platessa. Mean abundance and coefficient of variation of 0 -group plaice during egg and larval stages in the North Sea and subsequent juvenile stages in the Wadden Sea

\begin{tabular}{|c|c|c|c|c|c|}
\hline & Unit & Mean & $\begin{array}{l}\text { Coefficient of } \\
\text { variation }(\%)\end{array}$ & $\begin{array}{l}\text { No. of } \\
\text { years }\end{array}$ & Source \\
\hline \multicolumn{6}{|l|}{ Pelagic stage (North Sea) } \\
\hline Fertilized eggs & ind $\times 10^{12}$ & 4.33 & 40 & 10 & Harding et al. (1978) \\
\hline Stage V eggs & ind $\times 10^{12}$ & 0.88 & 41 & 10 & Harding et al. (1978) \\
\hline Stage I larvae & ind $\times 10^{12}$ & 0.17 & 95 & 4 & Harding et al. (1978) \\
\hline $\begin{array}{l}\text { Larval abundance near } \\
\text { the Wadden Sea }\end{array}$ & ind $1000 \mathrm{~m}^{-3}$ & 7.5 & 62 & 6 & $\begin{array}{l}\text { Creutzberg et al. (1978), } \\
\text { this study }\end{array}$ \\
\hline \multicolumn{6}{|l|}{ Demersal stage (Wadden Sea) } \\
\hline $\begin{array}{l}\text { Year-class index on the } \\
\text { Balgzand in May }\end{array}$ & ind $1000 \mathrm{~m}^{-2}$ & 114.6 & 62 & 9 & $\begin{array}{l}\text { Zijlstra et al. (1982), } \\
\text { this study }\end{array}$ \\
\hline $\begin{array}{l}\text { Year-class index on the } \\
\text { Balgzand in July }\end{array}$ & ind $1000 \mathrm{~m}^{-2}$ & 89.3 & 30 & 9 & $\begin{array}{l}\text { Zij]stra et al. (1982), } \\
\text { this study }\end{array}$ \\
\hline $\begin{array}{l}\text { Recruitment of } 2 y r \text { old plaice } \\
\text { to the parent stock in the North Sea }\end{array}$ & ind $\times 10^{6}$ & 298 & 35 & 9 & $\begin{array}{l}\text { International Wadden } \\
\text { Sea project (Anon. 1985) }\end{array}$ \\
\hline
\end{tabular}

with regard to the fixation of year-class strength: a fast coarse control during the period of egg or larval drift, followed by a second period of finer regulation later on in the early life of the fish.

The present study only considers population dynamic processes of 0 -group plaice in a very restricted area of the continental nursery and it might be questionable if extrapolation to total North Sea recruitment is allowable. Such processes can of course only be studied in sufficient detail in areas of in size of the western Wadden Sea or smaller. However, the fact that the plaice index of abundance in the Balgzand is significantly correlated with the arithmetic mean index for the whole continental Delta and Wadden Sea

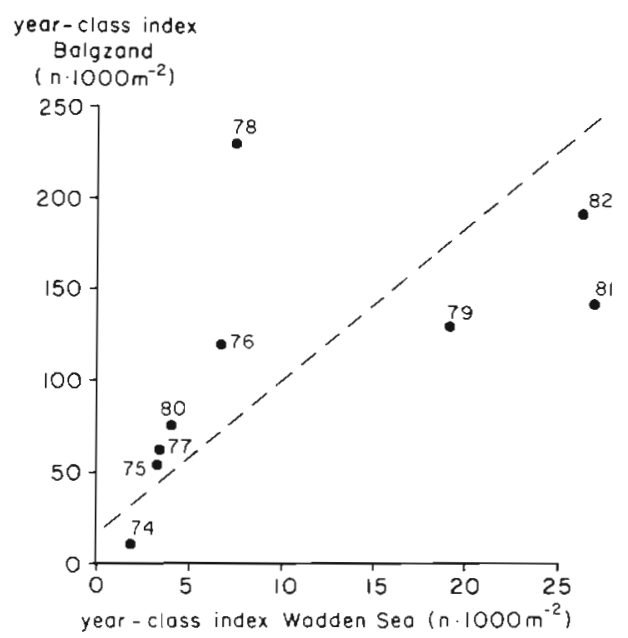

Fig. 14. Pleuronectes platessa. Relation between index of year-class strength of plaice in the Delta and Wadden Sea (International Wadden Sea project, Anon.1985) and index on the Balgzand (after Zijlstra et al. 1982 and this study) area obtained from the International Wadden Sea project (Anon. 1985), gives some credibility to such an approach (Fig. 14; $\mathrm{r}_{\mathrm{s}}=0.88 ; \mathrm{p}<0.05$ ).

Acknowledgements. A number of people participated in this study. Thanks are especially due to $M$. J. N. Bergman and J. IJ. Witte for their continuous support, to J. J. Zijlstra for his guidance and to G. P. Baerends, F. Creutzberg, N. Daan, B. R. Kuipers and Mrs G. van der Wolf for critical reading of the manuscript.

These investigations were supported by the Foundation for Fundamental Biological Research (BION), which is subsidized by the Netherlands Organization for the Advancement of Pure Research (ZWO).

\section{LITERATURE CITED}

Anonymous (1985). Report of the 0-group North Sea Flatfish Working Group, IJmuiden, 21-25 November 1983. Coun. Meet. int. Coun. Explor. Sea C. M.-ICES/G:2

Bannister, R. C. A. (1978). Changes in plaice stocks and plaice fisheries in the North Sea. Rapp. P.-v. Réun. Cons. int. Explor. Mer 172: 86-101

Bannister, R. C. A., Harding, D., Lockwood, S. J. (1974). Larval mortality and subsequent yearclass strength in the plaice (Pleuronectes platessa L.). In: Blaxter, J. H. S. (ed.) The early life history of fish. Springer, Berlin, p. 21-37

Bergman, M. Kuipers, B., Spliethoff, P., Veer, H. van der (1976). Garnalen en krabben als mogelijke predatoren van 0-jarige schol op het Balgzand. Visserij 29: 432-438

Berghahn, R. (1983). Untersuchungen an Plattfischen und Nordseegarnelen (Crangon crangon) im Eulitoral des Wattenmeeres nach dem Übergang zum Bodenleben. Helgoländer Meeresunters. 36: 163-181

Beukema, J. J. (1974). Seasonal changes in the biomass of the macro-benthos of a tidal flat area in the Dutch Wadden Sea. Neth. J. Sea Res. 8: 94-107

Boer, M. de (1978). Uitwisseling wadwater Balgzand waterloopkundig onderzoek mei 1977. Rapport Rijkswaterstaat, Directie Noord Holland Studiedienst Hoorn. H 7703A, p. $1-29$ 
Brander, K., Houghton, R. G. (1982). Predicting the recruitment of North Sea plaice from egg surveys. Coun. Meet. int. Coun. Explor. Sea C.M.-ICES/G: 5

Creutzberg, F., Fonds, M. (1971). The seasonal variation in the distribution of some demersal fish species in the Dutch Wadden Sea. Thalassia jugosl. 7: 13-23

Creutzberg, F., Eltink, A. Th. G. W., Noort, G. J. van (1978) The migration of plaice larvae Pleuronectes platessa into the western Wadden Sea. In: McLusky, D. S., Berry, A. J. (ed.) Physiology and behaviour of marine organisms. Proc. 12th Europ. mar. biol. Symp. Pergamon Press, New York, p. 243-251

Cushing, D. H. (1974). The possible density-dependance of larval mortality and adult mortality in fishes. In: Blaxter, J. H. S. (ed.) The early life history of fish. Springer, Berlin, p. $103-112$

Daan, N. (1978). Changes in cod stocks and cod fisheries in the North Sea. Rapp. P.-v. Réun. Cons. int. Explor. Mer 172: $39-57$

Dapper, R. (1978). De Balgzand scholgegevens 1975, 1976, 1977. Interne Verslagen Nederlands Instituut voor Onderzoek der Zee, Texel, 1978-12, p. 1-53

Dapper, R., Veern, H. W. van der (1981). Onderzoek naar de ruimtelijke variatie van de bodemsamenstelling op het Balgzand. Interne Verslagen Nederlands Instituut voor Onderzoek der Zee, Texel, 1981-9, p. 1-21

Edwards, R., Steele, J. H. (1968). The ecology of 0-group plaice and commen dab at Loch Ewe. I. Population and food. J. exp. mar. Biol. Ecol. 2: 215-238

Elliott, J. M. (1977). Some methods for the statistical analysis of samples of benthic invertebrates. Freshwater Biological Association, Scientific Publications No 25, Ambleside, p. $1-160$

Glazenburg, B. (1983). Een experimenteel onderzoek naar de groei van 0-groep schol en bot in relatie tot de watertemperatuur. Interne Verslagen Nederlands Instituut voor Onderzoek der Zee, Texel, 1983-5, p. 1-19

Gulland, J. A. (1965). Survival of the youngest stages of fish and its relation to year-class strength. Publs int. Commn. N.W Atlant. Fish 6: 365-371

Harding, D., Nichols, J. H., Tungate, D. S. (1978). The spawning of plaice (Pleuronectes platessa L.) in the southern North Sea and English Channel. Rapp. P.-v. Réun. Cons. int. Explor. Mer 172: 102-113

Hjort, J. (1914). Fluctuations in the great fisheries of Northern Europe viewed in the light of biological research. Rapp. P.-v. Réun. Cons. int. Explor. Mer 20: 1-228

Holden, M. J. (1978). Long-term changes in landings of fish from the North Sea. Rapp. P.-v. Réun. Cons. int. Explor. Mer 172: 11-26

Holling, C. S. (1959). The components of predation as revealed by a study of small mammal predation on the European pine sawfly. Can. Ent. 91: 293-320

Houghton, R. G., Harding, D. (1976). The plaice of the English Channel: spawning and migration. J. Cons. int. Explor. Mer 36: 229-239

Jones, R., Hislop, J. R. G. (1978). Changes in North Sea haddock and whiting. Rapp. P.-v. Réun. Cons. int. Explor. Mer 172: $58-71$

Kuipers, B. R. (1975). On the efficiency of a two metre beam trawl in juvenile plaice (Pleuronectes platessa). Neth. J. Sea. Res. 9: 69-85

Kuipers, B. R. (1977). On the ecology of juvenile plaice on a tidal flat in the Wadden Sea. Neth. J. Sea Res. 11: 56-91

Lockwood, S. J. (1972). An ecological survey of an 0-group plaice (Pleuronectes platessa L.) population, Filey Bay, Yorkshire. Thesis, Univ. East Anglia
Lockwood, S. J. (1973). Weight and length changes of 0-group plaice (Pleuronectes platessa L.) after preservation in $4 \%$ neutral formalin. J. Cons. int. Explor. Mer. 35: 100-101

Lockwood, S. J. (1980). Density-dependent mortality in 0 group plaice (Pleuronectes platessa L.) populations. J. Cons. int. Explor. Mer. 39: 148-153

Macer, C. T (1967). The food web in Red Wharf Bay (North Wales) with particular reference to young plaice (Pleuronectes platessa). Helgoländer wiss. Meeresunters. 15: $560-573$

Rauck, G. (1974). The arrival of different groups of young plaice in the German Wadden Sea. Ber. dt. wiss. Kommn Meeresforsch. 23: 273-288

Rauck, G., Zijlstra, J. J. (1978). On the nursery aspects of the Wadden Sea for some commercial fish species and possible long-term changes. Rapp. P.-v. Réun. Cons, int. Explor. Mer 172: 266-275

Rijnsdorp, A. D., Straten, M. van (1982). Selective tidal migration of plaice larvae (Pleuronectes platessa L.) in the Easter Scheldt and the western Wadden Sea. Coun. Meet. int. Coun. Explor. Sea C.M.-ICES/G: 31

Rijnsdorp, A. D., Straten, M. van, Veer, H. W. van der (1985). Selective tidal transport of North Sea plaice Pleuronectes platessa in coastal nursery areas. Trans. Am. Fish. Soc. 114: $461-470$

Riley, J. D., Corlett, J. (1966). The numbers of 0-group plaice in Port Erin Bay 1964-66. Rep. mar. biol. Stn Port Erin 78: $51-56$

Ryland, J. S. (1966). Observations on the development of larvae of the plaice, Pleuronectes platessa L. in aquaria. J. Cons. perm. int. Explor. Mer 30: 177-195

Sahrhage, D., Wagner, G. (1978). On fluctuations in the haddock population of the North Sea. Rapp. P.-v. Réun. Cons. int. Explor Mer 172: 72-85

Solomon, M. E. (1949). The natural control of animal populations. J. Anim. Ecol. 18: 1-35

Simpson, A. G. (1959). The spawning of the plaice in the North Sea. Fishery Invest. Lond. Ser. $222(7)$, p. 1-111

Steele, J. H., Edwards, R. R. C. (1970). The ecology of 0-group plaice and common dabs in Lock Ewe. IV. Dynamics of the plaice and dab populations. J. exp. mar. Biol. Ecol. 4: $174-187$

Talbot, J. W. (1976). The dispersal of plaice eggs and larvae in the Southern Bight of the North Sea. J. Cons. int. Explor. Mer 37: 221-248

Talbot, J. W. (1978). Changes in plaice larval dispersal in the last fifteen years. Rapp. P.-v. Réun. Cons. int. Explor. Mer 172: $114-123$

Veer, H. W. van der (1983). Een model voor de schatting van de watermassa met hoogwater aanwezig op de platen van het Balgzand. Interne Verslagen Nederlands Instituut voor Onderzoek der Zee, Texel, 1983-9, p. 1-12

Veer, H. W. van der (1985). Impact of coelenterate predation on larval plaice Pleuronectes platessa and flounder Platichthys flesus stock in the western Wadden Sea. Mar. Ecol. Prog. Ser. 25: 229-238

Veer, H. W. van der, Sadée, C. F. M. (1984). Seasonal occurrence of the ctenophore Pleurobrachia pileus in the western Dutch Wadden Sea. Mar. Biol. 79: 219-227

Vlas, J. de (1979). Annual food intake by plaice and flounder in a tidal flat area in the Dutch Wadden Sea, with special reference to consumption of regenerating parts of macrobenthic prey. Neth. J. Sea Res. 13: 117-153

Witte J. IJ., Zijlstra, J. J. (1984). The meiofauna of a tidal flat in the western part of the Wadden Sea and its role in the benthic ecosystem. Mar. Ecol. Prog. Ser. 14: 129-138

Zijlstra, J. J. (1972). On the importance of the Waddensea as a 
nursery area in relation to the conservation of the southern North Sea fishery resources. Symp. zool. Soc. Lond. 29: $233-258$

Zijlstra, J. J., Dapper, R., Witte, J. J. (1982). Settlement, growth and mortality of post-larval plaice (Pleuronectes platessa) in the western Wadden Sea. Neth. J. Sea Res. 15: $250-272$

Zijlstra, J. J., Witte, J. IJ. (1982). On the relation between length and abundance of North Sea plaice. Coun. Meet. int. Coun. Explor. Sea C.M.-ICES/G: 4

This article was submitted to the editor; it was accepted for printing on December 2, 1985 